\title{
ANALISIS MINAT MAHASISWA DALAM BERINVESTASI SAHAM PADA GALERI BURSA EFEK INDONESIA FAKULTAS EKONOMI UNIVERSITAS MADURA
}

\author{
Subhan \\ subhan@unira.ac.id \\ Ah. Suryansyah \\ soerjansjah@gmail.com \\ Prodi Akuntansi Fakultas Ekonomi UniversitasMadura
}

\begin{abstract}
The Faculty of Economics is one of the faculties at Madura University that has an investment gallery. through this galerry, it will be a medium for Madura University student to invest shares in the capital market. the purpose of this study is to determine the effect of capital market education, minimal investment capitak, and return on student interest in investing in stocks.

This type of research is quantitative associative. the data used are primary data obtained through the distribution of questionnaires to 275 respondent, namely 183 students of management study programs and 92 students of accounting study programs at the Faculty of Economics, University of Madura. the sampling method used by researches in each study program was proportionate stratified random sampling.

The results of this study indicate that capital market education, minimal invesment capital and returns partially have a siginificant effect on students' interest in investing in stocks.
\end{abstract}

Key Words: Interest Investment, Capital Market Education, Minimum Investment Capital, Return

\begin{abstract}
ABSTRAK
Fakultas Ekonomi merupakan salah satu fakultas di universitas madura memiliki galeri investasi. Melalui galeri iniakan menjadi media bagi mahasiswa Universitas Madura untuk berinvestasi saham di pasar modal.Tujuan penelitian ini untuk mengetahui pengaruh edukasi pasar modal, modal investasi minimal, dan return pada minat mahasiswa berinvestasi saham.

Jenis penelitian ini adalahkuantitatif asosiatif. Data yang digunakan adalah data primeryang diperoleh melalui penyebaran kuesioner kepada 275 responden yaitu 183 mahasiswa program studi manajemen dan 92 mahasiswa program studiakuntansi Fakultas Ekonomi Universitas Madura. Metode pengambilan sampel yang digunakan peneliti pada setiap prodi adalah proportionate stratified random sampling.

Hasil penelitian ini menunjukkan bahwa edukasi pasar modal, modal investasi minimal, dan return secara parsial berpengaruh signifikan terhadap minat mahasiswa berinvestasi saham.
\end{abstract}

Kata Kunci : Minat Investasi, Edukasi Pasar Modal, Modal Investasi Minimal, Return 


\section{PENDAHULUAN}

Investasi di pasar modal merupakan salah satu alternatif investasi yang mudah diakses oleh masyarakat luas semenjak dibukanya Bursa EfekIndonesia. Pasar modal di Indonesia yaitu Bursa Efek Indonesia (BEI) dapat menjadi media pertemuan antara investor dan industri. Melalui pasar modal, pemilik modal dapat dengan mudah menyalurkan dananya ke sektor yang produktif. Namun di Indonesia, aktivitas investasi masih cukup rendah jika dibandingkan dengan negara lain. Rendahnya masyarakat Indonesia berinvestasi mungkin disebabkan oleh minimnya pengetahuan mengenai investasi di pasar modal.

Bursa Efek Indonesia (BEI) mengadakan program sosialisasi dan edukasi mengenai investasi di pasar modal, khususnya kepada kalangan akademisi di kampus. Mahasiswa merupakan salah satu calon investor muda yang paling menarik karena telah memiliki dasar pengetahuan investasi yang diberikan pada mata kuliah Analisis Investasi dan Teori Portofolio. Mahasiswa diharapkan menjadi segmen masyarakat yang berkontribusi aktif dalampeningkatan investasi di pasar modal.

Fakultas Ekonomi merupakan salah satu fakultas di universitas madura yang telah memiliki galeri investasi, dibukanya galeri investasi merupakan program kerja sama antara Fakultas Ekonomi dengan Bursa Efek Indonesia dan PT. MNC Sekuritas. Dengan adanya galeri investasi, diharapkan menjadi sarana bagi mahasiswa Universitas Madura untuk terjun langsung dalam dunia investasi pasar modal dan untuk mempraktekkan teori yang telah didapatkan dalam perkuliahan.

Investasi adalah komitmen atas sejumlah dana atau sumberdaya lainnya yang dilakukan pada saat ini, dengan tujuan memperoleh sejumlah keuntungan di masa datang. Pasar modal memberikan alternatif bagi investor untuk berinvestasi baik dalam jangka pendek maupun panjang, yang pada umumnya akan menyebabkan para investor tertarik untuk menginvestasikan dananya.

Saham merupakan salah satu komoditas keuangan yang di perdagangan di pasar modal yang paling populer. Saham adalah surat berharga yang menunjukkan bagian kepemilikan atas suatu perusahaan. Saham berwujud selembar kertas yang menerangkan bahwa pemilik kertas adalah pemilik perusahaan yang menerbitkan surat berharga. Porsi kepemilikan ditentukan oleh seberapa besar penyertaan yang ditanamkan di perusahaan.

Sebelum melakukaninvestasi, tentunya investor harus mengetahui dan mempelajari setiap hal yang berkaitan dengan investasi. Beberapa hal diduga mempengaruhi minat seseorang untuk melakukan investasi, yaitu edukasi tentang pasar modal, modal investasi minimal dan hasil yang diperoleh dari investasi.

Berdasarkan uraian tersebut perlu dilakukan pengkajian variabel-variabel yang mempengaruhi mina mahasiswa dalam berinvestasi saham. Adapun variabel yang diteliti adalah; eduksi pasar modal, modal investasi minimal dan return, selanjutnya akan menganalisis variabel-variabel yang mempengaruhi minat mahasiswa dalam berinvestasi.

\section{KAJIAN PUSTAKA}

\section{PenelitianTerdahulu}

Penelitian Raditya dkk (2014)tentangPengaruh Modal Investasi Minimal di BNI Sekuritas, Return dan Persepsi Terhadap Risiko Pada Minat Investasi Mahasiswa, dengan Penghasilan Sebagai Variabel Moderasi menunjukkan bahwa modal investasi minimal tidak berpengaruh terhadap minat investasi, persepsi terhadap risiko 
berpengaruh pada variabel minat investasi, return berpengaruh pada variabel minat investasi, penghasilan tidak mampu memoderasi hubungan variabel modal investasi minimal dengan minat investasi, return dengan minat investasi, serta persepsi terhadap risiko dengan minat investasi.

Penelitian Merawati dan Putra (2015)tentangKemampuan Pelatihan Pasar Modal Memoderasi Pengaruh Pengetahuan Investasi Dan Penghasilan Pada Minat Berinvestasi Mahasiswamenunjukkanpengetahuan investasi dan penghasilan berpengaruh positif signifikan pada minat investasi mahasiswa. Penelitian ini juga berhasil menemukan bahwa program edukasi yang dilakukan oleh pojok Bursa Unmas Denpasar yakni pelatihan pasar modal belum mampu memoderasi hubungan antara pengetahuan investasi dan penghasilan dengan minat berinvestasi mahasiswa Fakultas Ekonomi Unmas Denpasar.

Penelitian Tandio dan Widanaputra (2016)tentangPengaruh Pelatihan Pasar Modal, Return, Persepsi Risiko, Gender, dan Kemajuan Teknologi Pada Minat Investasi Mahasiswadi Fakultas Ekonomi dan Bisnis Universitas Udayana. Berdasarkan hasil analisis regresi yang dilakukan, pelatihan pasar modal dan return mempengaruhi minat investasi secara signifikan. Sedangkan variabel persepsi risiko, gender dan kemajuan teknologi tidak mempengaruhi minat investasi secara signifikan.

Penelitian Nisa dan Zulaika (2017)tentangPengaruh Pemahaman Investasi, Modal Minimal Investasi dan Motivasi terhadap Minat Mahasiswa Berinvestasi di Pasar Modalpada mahasiswa STIE Kesuma Negara Blitarmenunjukkan bahwa pemahaman investasi yang diperoleh mahasiswa ketika mendapat matakuliah manajemen investasi dan pasar modal tidak berpengaruh terhadap minat mahasiswa untuk berinvestasi di pasar modal. Namun, dengan adanya modal minimal yang kecil dan motivasi dari diri sendiri maupun orang lain sangat mempengaruhi mahasiswa untuk berinvestasi di pasar modal.

\section{Minat}

W. S Winkel mengatakan bahwa minat adalah kecenderungan yang agak menetap untuk merasa tertarik pada bidang-bidang tertentu dan merasa senang berkecimpung dalam bidang itu (1983 : 38), sedangkan menurut Witherington (1985 : 38) minat adalah kesadaran seseorang terhadap suatu objek, seseorang, suatu soal atau situasi tertentu yang mengadung sangkut paut dengan dirinya atau dipandang sebagai sesuatu yang sadar.

Minat merupakan bentuk sikap seseorang berupa rasa lebih suka dan rasa keterikatan terhadap suatu hal atau aktivitas tanpa ada yang menyuruh. Minat (Marpaung, 2010) adalah perasaan suka atau tidak suka seseorang terhadap suatu objek baik peristiwa maupun benda. Pengukuran minat dapat dilakukan melalui serangkaian daftar pertanyaan.

"Theory of Reasoned Action (Ajzen, 1985) dalam Daniel Raditya (2014) menyatakan bahwa perilaku seseorang ditentukan oleh suatu intensi, yang merupakan fungsi dari tingkah laku terhadap perilaku norma subjektif. Intensi mampu memprediksi perilaku dengan sangat baik. Intensi merupakan representasi kognitif dari kesiapan seorang untuk berperilaku, yang merupakan awal terbentuknya awal perilaku seseorang. Intensi ini ditentukan oleh tiga hal yaitu tingkah laku, norma subyektif dan pengendalian perilaku". 
Theory of Planned Behavior (pengembangan dari Theory of Reasoned Action) menyatakan bahwa dari ketiga poin tersebut, tingkah laku merupakan poin utama yang mampu memprediksi sebuah prilaku. Mengukur tingkah laku, harus disertakan dengan mengukur norma subjektif seseorang terlebih dahulu (keyakinan mengenai orang-orang yang mereka sayangi, yang akan menunjukkan bagaimana nantinya mereka akan berperilaku). Jika ingin memprediksi intensi seseorang, maka mengetahui keyakinan tersebut sama pentingnya dengan mengetahui sikap seseorang. Kemudian pengendalian perilaku akan mempengaruhi intensi. Pengendalian perilaku mengacu pada persepsi seseorang atas kemampuan mereka untuk berperilaku. Terakhir, norma subyektif akan menunjukkan bagaimana seseorang berperilaku. Ketiga prediktor tersebut akhirnya akan menyimpulkan intensi seseorang. Semakin kuat tingkah laku, norma subjektif serta semakin besar pengendalian perilaku seseorang, semakin kuat intensi mereka untuk berperilaku terhadap kondisi tertentu

Sedangkan menurut Sumadi Suryabrata (2002:68) definisi minat adalah "Suatu rasa lebih suka dan rasa ketertarikan pada suatu hal atau aktivitas tanpa ada yang menyuruh". Minat pada dasarnya adalah penerimaan akan suatu hubungan antara diri sendiri dengan sesuatu hal diluar dirinya. Semakin kuat atau dekat hubungan tersebut semakin besar minatnya. Minat dapat diartikan sebagai "Kecenderungan yang tinggi terhadap sesuatu, tertarik, perhatian, gairah dan keinginan". Pendapat lain tentang pengertian minat yaitu yang diungkapkan oleh $\mathrm{T}$. Albertus yang diterjemahkan Sardiman A.M, minat adalah "Kesadaran seseorang bahwa suatu obyek, seseorang, suatu soal maupun situasi yang mengandung sangkut paut dengan dirinya" (2006:32).

Karakteristik Minat Ada beberapa macam karakteristik minat, antara lain :

a. Minat menimbulkan sikap positif terhadap suatu obyek.

b. Adanya sesuatu yang menyenangkan yang timbul dari sesuatu obyek.

c. Mengandung suatu penghargaan menimbulkan keinginan atau gairah untuk mendapatkan sesuatu yang menjadi keinginan atau gairah untuk mendapatkan sesuatu yang menjadi minatnya.

\section{Cara Pembentukan Minat}

Minat pada dasarnya dapat dibentuk dalam hubungannya dengan obyek. Yang paling berperan dalam pembentukan minat selanjutnya dapat berasal dari orang lain, meskipun minat dapat timbul dari dalam dirinya sendiri. Adapun pembentukan minat dapat dilakukan dengan caracara sebagai berikut :

a. Memberikan informasi yang seluas-luasnya, baik keuntungan maupun kerugian yang ditimbulkan oleh obyek yang dimaksud. Informasi yang diberikan dapat berasal dari pengalaman, media cetak, media elektronik.

b. Memberikan rangsangan, dengan cara memberikan hadiah berupa barang atau sanjungan yang dilakukan individu yang berkaitan dengan obyek

c. Mendekatkan individu terhadap obyek, dengan cara membawa individu kepada obyek atau sebaliknya mengikutkan individu-individu pada kegiatan-kegiatan yang diselenggarakan oleh obyek yang dimaksud.

d. Belajar dari pengalaman. 


\section{Investasi}

Menurut Halim (2005;4) "Investasi pada hakikatnya merupakan penempatan sejumlah dana dengan harapan memperoleh keuntungan di masa mendatang". Sharpe (2005;1) dalam Kusmawati (2011) menambahkan bahwa pengorbanan yang dikeluarkan saat ini bersifat pasti dan keuntungan yang diharapkan bersifat tidak pasti. Investasi dilakukan didasari oleh adanya kebutuhan masa depan atau kebutuhan saat ini yang belum mampu untuk dipenuhi saat ini, adanya keinginan untuk menambah nilai aset, serta adanya kebutuhan untuk melindungi nilai aset yang sudah dimiliki karena adanya inflasi. Menurut Tandelilin (2001;3) "Investasi adalah komitmen atas sejumlah dana atau sumberdaya lainnya yang dilakukan pada saat ini, dengan tujuan memperoleh sejumlah keuntungan di masa datang". Investasi bisa berkaitan dengan berbagai macam aktivitas. Menginvestasikan sejumlah dana pada aset riil (tanah, emas, mesin atau bangunan), maupun aset financial (deposito, saham ataupun obligasi) merupakan aktivitas investasi yang umumnya dilakukan.

\section{Tujuan Investasi}

Tujuan melakukan investasi adalah untuk menghasilkan sejumlah uang. Tujuan investasi yang lebih luas adalah untuk meningkatkan kesejahteraan investor. Kesejahteraan dalam hal ini adalah kesejahteraan moneter, yang bisa diukur dengan penjumlahan pendapatan saat ini ditambah nilai saat ini pendapatan masa datang.

Secara lebih khusus lagi, ada beberapa alasan melakukan investasi, antara lain adalah:

a. Untuk mendapatkan kehidupan yang lebih layak di masa mendatang.

Seseorang yang bijaksana akan berpikir bagaimana meningkatkan taraf hidupnya dari waktu ke waktu atau setidaknya berusaha bagaimana mempertahankan tingkat pendapatannya yang ada sekarang agar tidak berkurang di masa yang akan datang.

b. Mengurangi tekanan inflasi.

Dengan melakukan investasi dalam pemilikan perusahaan atau objek lain, seseorang dapat menghindarkan diri dari risiko penurunan nilai kekayaan atau hak miliknya akibaht adanya pengaruh inflasi.

c. Dorongan untuk menghemat pajak

Beberapa negara di dunia banyak melakukan kebijakan yang bersifat mendorong tumbuhnya investasi di masyarakat melalui pemberian fasilitas perpajakan kepada masyarakat yang melakukan investasi pada bidang-bidang usaha tertentu.

\section{Tipe-Tipe Investasi}

Investasi ke dalam aktiva keuangan dapat berupa investasi langsung dan investasi tidak langsung. Investasi langsung dilakukan dengan membeli langsung aktiva keuangan dari suatu perusahaan baik melalui perantara atau dengan cara yang lain. Sebaliknya investasi tidak langsung dilakukan dengan membeli saham dari perusahaan investasi yang mempunyai portofolio aktiva-aktiva keuangan dari perusahaan-perusahaan lain.

\section{a. Investasi Langsung}

Investasi langsung dapat dilakukan dengan membeli aktiva keuangan yang dapat diperjualbelikan di pasar uang, pasar modal, atau pasar turunan. Investasi langsung juga dapat dilakukan dengan membeli aktiva keuangan yang tidak dapat diperjualbelikan. Aktiva keuangan yang tidak dapat diperjualkan biasanya diperoleh melalui 
bank komersial. Aktiva-aktiva ini dapat berupa tabungan di bank atau sertifikat deposito.

Pasar modal sifatnya adalah untuk investasi jangka-panjang. Yang diperjualbelikan di pasar modal adalah aktiva keuangan berupa surat-surat berharga pendapatan-tetap dan saham-saham. Aktiva yang dapat diperjual-belikan di equity market adalah preferred stock dan common stock.

Opsi dan futures contract merupakan surat berharga yang diperdagangkan di pasar turunan. Disebut dengan surat-surat berharga turunan karena nilainya merupakan jabaran dari surat berharga lain yang terkait. Contoh dari opsi adalah waran. Waran adalah suatu hak yang diberikan kepada pemegangnya untuk membeli saham dari perusahaan bersangkutan dengan harga yang tertentu dalam kurun waktu yang sudah ditentukan. Futures contract merupakan persetujuan untuk menyediakan aktiva di masa mendatang dengan harga pasar yang sudah ditentukan di muka. Aktiva yang diperdagangkan umunya adalah komoditi hasil bumi.

\section{b. Investasi Tidak Langsung}

Investasi tidak langsung dilakukan dengan membelli surat-surat berharga dari perusahaan investasi. Perusahaan investasi adalah perusahaan yang menyediakan jasa keuangan dengan cara menjual sahamnya ke publik dan menggunakan dana yang diperoleh untuk diinvestasikan ke dalam portofolionya. Perusahaan investasi dapat diklasifikasikan sebagai unit investment trust, clossed-end investment companies dan open-end investment companies.

Unit investment trust merupakan trust yang menerbitkan portofolio yang dibentuk dari surat-surat berharga berpenghasilan tetap (misalnya bond) dan ditangani oleh orang kepercayaan yang independen. Sertifikat portofolio ini dijual kepada investor sebesar nilai bersih total aktiva yang tergabung di dalam portofolio ditambah dengan komisi. Investor dapat menjual balik sertifikat ini kepada trust sebesar nilai bersih sertifikat tersebut (net asset value atau NAV). Besarnya NAV per-sertifikat adalah total nilai pasar dari sekuritas-sekuritas yang tergabung di portofolio dikurangi dengan biaya-biaya yang terjadi dan dibagi dengan jumlah sertifikat yang diedarkan.

Closed-end investment companies merupakan perusahaan investasi yang hanya menjual sahamnya pada saat penawaran perdana (initial public offering) saja dan selanjutnya tidak menawarkan lagi tambahan lembar saham. Lembar saham yang sudah beredar dari penawaran perdana diperdagangkan di pasar sekunder dengan harga pasar yang terjadi di pasar bursa.

Open-end investment companies dikenal dengan nama perusahaan reksa dana (mutual funds). Perusahaan investasi ini masih menjual saham baru kepada investor setelah penjualan saham perdananya. Juga pemegang saham dapat menjual kembali sahamnya ke perusahaan reksa dana bersangkutan.

\section{Saham}

Saham merupakan salah satu instrumen pasar modal yang paling diminati investor karena memberikan tingkat keuntungan yang menarik. Saham dapat didefinisikan sebagai tanda penyetaan modal seorang atau sepihak (badan usaha) dalam suatu perusahaan atau perseroan terbatas. Dengan menyertakan modal tersebut, maka pihak tersebut memiliki klaim atas pendapatan perusahaan, klaim atas aset perusahaan, dan berhak hadir dalam rapat umum pemegang saham (RUPS). 
Ada berbagai alasan mengapa perusahaan berkepentingan untuk menjual sahamnya, tapi pada umumnya adalah untuk menambah modal kerja atau membiayai pengembangan perusahaan. Penjualan saham biasanya dilakukan melalui bursa, dalam hal ini kepada masyarakat guna untuk menambah modal kerja, perluasan perusahaan, atau untuk produk timbal balik, dari kesemua itu pemegang saham akan menerima keuntungan dari perusahaan yang menerbitkan saham.

Menurut Tandelilin $(2001 ; 18)$ "saham merupakan surat bukti bahwa kepemilikan atas aset-aset perusahaan yang menerbitkan saham". Dengan memiliki saham suatu perusahaan, maka investor akan mempunyai hak terhadap pendapatan dan kekayaan perusahaan, setelah dikurangi dengan pembayaran semua kewajiban perusahaan.

Menurut Husnan Suad (2008:29) pengertian saham adalah sebagai berikut "Saham adalah secarik kertas yang menunjukkan hak pemodal yaitu pihak yang memiliki kertas tersebut untuk memperoleh bagian dari prospek atau kekayaan organisasi yang menerbitkan sekuritas tersebut, dan berbagai kondisi yang memungkinkan pemodal tersebut menjalankan haknya". Sedangkan menurut Fahmi (2012:81) "Saham merupakan salah satu instrument pasar modal yang paling banyak diminati oleh investor, karena mampu memberikan tingkat pengembalian yang menarik. Saham adalah kertas yang tercantum dengan jelas nilai nominal, nama perusahaan, dan diikuti dengan hak dan kewajiban yang telah dijelaskan kepada setiap pemegangnya".

Saham dapat didefinisikan sebagai tanda penyertaan atau pemilikan seorang atau badan dalam suatu perusahaan atau perseroan terbatas. Saham berwujud selembar kertas yang menerangkan bahwa pemilik kertas tersebut adalah pemilik perusahaan yang menerbitkan surat berharga tersebut. Porsi kepemilikan ditentukan oleh seberapa besar penyertaan yang ditanamkan di perusahaan tersebut.

Saham yang diperdagangkan di bursa ada dua jenis yaitu saham biasa (common stock) dan saham preferen (prefered stock) (Anoraga 2006:54). Saham biasa (common stock) adalah saham yang menempatkan pemiliknya pada posisi yang paling junior dalam pembagian dividen dan hak atas kekayaan perusahaan apabila perusahaan tersebut dilikuidasi. Sedangkan saham preferen (prefered stock) adalah saham yang memiliki karakteristik gabungan antara obligasi dan saham biasa, karena bisa menghasilkan pendapatan yang tetap, tetapi juga bisa tidak mendatangkan hasil seperti yang dikehendaki investor (Darmadji, 2006:7). Dari kedua jenis saham tersebut, saham biasa yang paling banyak diperdagangkan di pasar modal.

\section{Pasar Modal}

Menurut Tandelilin $(2001 ; 13)$ "pasar modal adalah pertemuan antara pihak yang memiliki kelebihan dana dengan pihak yang membutuhkan dana dengan cara memperjualbelikan sekuritas". Pasar modal juga bisa diartikan sebagai pasar untuk memperjualbelikan sekuritas yang umumnya memiliki umur lebih dari satu tahun, seperti saham. Sedangkan tempat dimana terjadinya jual beli sekuritas disebut dengan bursa efek. Bursa efek merupakan arti dari pasar modal secara fisik.

Pasar modal dapat juga berfungsi sebagai lembaga perantara pasar (intermediaries). Fungsi ini menunjukkan peran penting pasar modal dalam menunjang perekonomian karena pasar modal dapat menghubungkan pihak yang membutuhkan dana dengan pihak yang mempunyai kelebihan dana. Dana yang 
berasal dari investor dapat digunakan secara produktif oleh perusahaan-perusahaan tersebut.

Dana yang didapatkan perusahaan melalui penjualan sekuritas (saham) merupakan hasil perdagangan saham-saham perusahaan yang dilakukan di pasar perdana. Di pasar perdana, perusahaan untuk pertama kalinya menjual sekuritasnya, dan proses itu disebut dengan Initial Public Offering (IPO) atau penawaran umum. Setelah sekuritas dijual perusahaan di pasar perdana, kemudian sekuritas diperjualbelikan oleh investor-investor di pasar sekunder atau disebut juga pasar reguler. Transaksi yang dilakukan investor di pasar sekunder tidak akan memberikan tambahan dana lagi bagi perusahaan yang menerbitkan sekuritas (emiten), karena transaksi hanya terjadi antar investor, bukan dengan perusahaan.

\section{Edukasi Pasar Modal}

Edukasi diartikan perihal yang berkenaan dengan pendidikan (Kamus Besar Bahasa Indonesia, 2001;284). Menurut Tandelilin (2001;13) "pasar modal adalah pertemuan antara pihak yang memiliki kelebihan dana dengan pihak yang membutuhkan dana dengan cara memperjualbelikan sekuritas". Jadi edukasi pasar modal dapat diartikan sebagai pendidikan yang berkenaan dengan pertemuan antara pihak yang memiliki kelebihan dana dengan pihak yang membutuhkan dana dengan cara memperjualbelikan sekuritas. Edukasi mengenai pasar modal bisa dalam bentuk seperti matakuliah mengenai investasi dan pasar modal, seminar-seminar investasi, pelatihan pasar modal, sosialisasi pasar modal maupun melalui galeri investasi.

Edukasi tentang pasar modal kepada masyarakat adalah hal penting dalam melakukan aktivitas investasi. Edukasi pasar modal bertujuan agar masyarakat dan mahasiswa lebih mengetahui tentang pasar modal, memahami pentingnya berinvestasi, mengenal saham sebagai alat investasi yang ideal, memahami kendalakendala sekaligus menarik minat masyarakat sebagai calon investor untuk berinvestasi di pasar modal Indonesia.

Edukasi dan sosialisasi kepada masyarakat di daerah-daerah untuk mendapatkan calon investor adalah langkah yang dilakukan pemerintah supaya menambah kontribusi masyarakat nantinya ke pasar modal. Pemerintah melalui campaign "Yuk Nabung Saham" diharapkan untuk terus mencetak investor-investor cerdas yang akan ikut serta membantu pertumbuhan pasar modal.

Investor Saham Pemula (ISP) merupakan komunitas sosial (social community) yang berfokus pada bidang edukasi pasar modal. Anggota Komunitas ISP tidak dikhususkan untuk kalangan pemuda-pemudi, namun untuk seluruh masyarakat Indonesia dari berbagai latar belakang dan usia. Komunitas ISP berusaha untuk terus berperan aktif dalam membantu masyarakat Indonesia agar melek investasi pasar modal, tidak hanya kalangan akademisi tapi juga masyarakat dari berbagai kelas. Galeri Investasi BEI juga sebagai pusat sosialisasi dan edukasi bagi masyarakat yang ingin berinvestasi di pasar modal serta juga menyediakan informasi tentang aktivitas perdagangan di pasar saham maupun instrumen pasar modal lainnya. Informasi dan data yang ada di Galeri Investasi BEI dapat digunakan oleh civitas akademika untuk tujuan akademik dan penelitian, disamping sebagai referensi dalam pengambilan keputusan saat melakukan transaksi jual dan beli Efek. Selain memberi informasi secara teoritis, di Galeri Investasi BEI masyarakat dan pihak kampus juga bisa praktik bagaimana melakukan transaksi di pasar saham. 
Dengan adanya Galeri Investasi BEI diharapkan dapat saling memberikan manfaat bagi semua pihak sehingga penyebaran informasi pasar modal lebih tepat sasaran. Selain itu dapat memberikan manfaat yang optimal bagi mahasiswa, praktisi ekonomi, investor, pengamat pasar modal maupun masyarakat umum di daerah, baik untuk kepentingan edukasi dengan dilakukannya kegiatan sosialisasi pasar modal secara berkesinambungan maupun untuk kepentingan ekonomis atau sarana investasi.

\section{Modal Investasi Minimal}

Peraturan di bursa efek indonesia, jumlah minimal pembelian saham dari suatu emiten (perusahaan yang menjual sahamnya ke publik) adalah sebanyak 1 lot $=100$ lembar. Sementara harga minimal saham yang diperdagangkan di BEI adalah Rp 50,per lembar.

Investasi saham saat ini dapat dimulai dengan modal minim. Hal ini tentu akan membuat investasi saham jauh lebih terjangkau bagi masyarakat dari berbagai kalangan yang tidak punya banyak dana namun ingin berinvestasi. Bagi para pelajar dan mahasiswa, mereka dapat memulai investasi saham tanpa perlu khawatir dengan penggunaan modal yang besar, serta dapat dijadikan sebagai sarana pembelajaran.

Untuk mulai membeli saham setiap investor harus membuka rekening di sebuah sekuritas atau sering disebut broker, sebagai lembaga resmi yang menjadi perantara antara satu investor dengan investor lain. Setiap sekuritas/broker memiliki ketentuan masing-masing akan modal minimal yang harus dideposit ketika membuka rekening, saat ini di beberapa sekuritas dana awal yang harus disetor berkisar sebesar Rp 100.000,-.

Modal yang disetor ketika membuka rekening tidak harus dibelanjakan seluruhnya, beberapa saat setelah proses pembukaan rekening selesai, dapat mentransfer kembali sebagian dari modal yang disetor, dan menyisakan sejumlah yang ingin diinvestasikan saja.

\section{Return}

Tujuan investor dalam berinvestasi adalah memaksimalkan return, tanpa melupakan faktor resiko investasi yang harus dihadapinya. Return merupakan hasil yang diperoleh dari investasi. Menurut Tandelilin $(2001 ; 47)$ "Return merupakan salah satu faktor yang memotivasi investor berinvestasi dan juga merupakan imbalan atas keberanian investor menanggunng risiko atas investasi yang dilakukannya".

Sumber-sumber return investasi terdiri dari dua komponen utama, yaitu yield dan capital gain (loss). Yield merupakan komponen return yang mencerminkan aliran kas atau pendapatan yang diperoleh secara periodik dari suatu investasi. Misalnya jika membeli saham, yield ditunjukkan oleh besarnya deviden yang diperoleh.Sedangkan, capital gain (loss) sebagai komponen kedua dari return merupakan kenaikan (penurunan) harga suatu surat berharga, yang bisa memberikan keuntungan (kerugian) bagi investor.

Pasar yang efisien adalah pasar dimana return semua sekuritas yang diperdagangkan telah mencerminkan semua informasi yang tersedia. Dalam hipotesis pasar modal yang efisien dikatakan bahwa pasar yang efisien akan bereaksi cepat terhadap informasi yang relavan. Sharpe dan Brealy dan Myers dalam Indrawijaya (2001) menekankan bahwa pengertian pasar yang efisien adalah pasar dimana seorang investor tidak mendapatkan keuntungan yang berlebihan atau abnorm return. 
Dalam studi analisa efisiensi pasar modal setengah kuat dengan menggunakan metode event study, penelitian dilakukan dengan melihat pergerakan saham selama event windows yang tercermin dari return saham tersebut dibandingkan dengan return ekspektasi apabila diasumsikan peristiwa tersebut tidak terjadi. Selisih antara return yang terjadi karena peristiwa tersebut dan return ekspektasi peristiwa tersebut tidak terjadi adalah return abnormal.

\section{HIPOTESIS}

\section{Pengaruh Edukasi Pasar Modal Terhadap Minat Investasi}

Edukasi mengenai pasar modal bisa dalam bentuk seperti matakuliah mengenai investasi dan pasar modal, seminar-seminar investasi, pelatihan pasar modal, sosialisasi pasar modal maupun melalui galeri investasi. Edukasi tentang pasar modal kepada masyarakat adalah hal penting dalam melakukan aktivitas investasi. Edukasi pasar modal bertujuan agar masyarakat dan mahasiswa lebih mengetahui tentang pasar modal, memahami pentingnya berinvestasi, mengenal saham sebagai alat investasi yang ideal, memahami kendala-kendala sekaligus menarik minat masyarakat sebagai calon investor untuk berinvestasi di pasar modal Indonesia.

Penelitian Merawati dan Putra (2015) yang menyatakan bahwa edukasi pasar modal dengan melalui pengetahuan investasi berpengaruh positif signifikan pada minat mahasiswa untuk berinvestasi. penelitianinididukung oleh Tandio dan Widanaputra (2016) yang menyimpulkan bahwa edukasi pasar modal dengan melalui pelatihan pasar modal mempengaruhi minat investasi secara signifikan. Namunberbedadenganhasilpenelitian Nisa dan Zulaika (2017) yang menyimpulkan bahwa edukasi pasar modal dengan melalui pemahaman investasi tidak berpengaruh terhadap minat mahasiswa untuk melakukan investasi. Berdasarkan penelitian di atasmaka hipotesis adalah:

$\mathrm{H}_{\mathrm{a} 1}$ : Edukasi pasar modal berpengaruh terhadap minat mahasiswaberinvestasi saham pada Galeri Investasi Bursa Efek Indonesia Fakultas Ekonomi Universitas Madura.

\section{Pengaruh Modal Investasi Minimal Terhadap Minat Investasi}

Investasi saham saat ini dapat dimulai dengan modal minim. Modal minimal yang harus dideposit ketika membuka rekening, saat ini di beberapa sekuritas dana awal yang harus disetor berkisar sebesar Rp 100.000,-. Jumlah minimal pembelian saham dari suatu emiten (perusahaan yang menjual sahamnya ke publik) adalah sebanyak 1 lot = 100 lembar. Sementara harga minimal saham yang diperdagangkan di BEI adalah Rp 50,- per lembar. Hal ini tentu akan membuat investasi saham jauh lebih terjangkau bagi masyarakat dari berbagai kalangan yang tidak punya banyak dana namun ingin berinvestasi. Bagi para pelajar dan mahasiswa, mereka dapat memulai investasi saham tanpa perlu khawatir dengan penggunaan modal yang besar, serta dapat dijadikan sebagai sarana pembelajaran.

Penelitian Raditya dkk (2014) yang menyatakan bahwa modal investasi minimal tidak berpengaruh terhadap minat mahasiswa untuk melakukan investasi. Penelitian inibertolakbelakangdengan penelitianNisa dan Zulaika (2017) yang menyimpulkan bahwa modal investasi minimal sangat berpengaruh terhadap minat mahasiswa untuk melakukan investasi, hal ini menunjukkan bahwa mahasiswa akan cenderung melakukan investasi apabila modal minimal untuk berinvestasi semakin kecil. Maka hipotesis kedua adalah: 
$\mathrm{H}_{\mathrm{a} 2}$ : Modal investasi minimal berpengaruh terhadap minat mahasiswa berinvestasi saham pada Galeri Investasi Bursa Efek Indonesia Fakultas Ekonomi Universitas Madura.

\section{Pengaruh Return Terhadap Minat Investasi}

Tujuan investor dalam berinvestasi adalah memaksimalkan return, tanpa melupakan faktor resiko investasi yang harus dihadapinya. Return merupakan hasil yang diperoleh dari investasi. Return juga merupakan salah satu faktor yang memotivasi investor berinvestasi dan juga merupakan imbalan atas keberanian investor menanggunng risiko atas investasi yang dilakukannya.

Penelitian Raditya dkk (2014) yang menyatakan bahwa return berpengaruh terhadap minat mahasiswa melakukan investasi. Senada dengan Penelitian yang dilakukan oleh Tandio dan Widanaputra (2016) yang menyimpulkan bahwa return mempengaruhi minat investasi secara signifikan. Maka hipotesis ketiga adalah:

$\mathrm{H}_{\mathrm{a} 3}$ : Return berpengaruh terhadap minat mahasiswa berinvestasi saham pada Galeri Investasi Bursa Efek Indonesia Fakultas Ekonomi Universitas Madura.

\section{METODE PENELITIAN}

\section{Jenis Penelitian}

Jenis penelitian dalam penelitian ini adalah jenis penelitian kuantitatif asosiatif, karena data yang digunakan berupa data hasil jawaban dari kuesioner. Menurut Siregar $(2013 ; 7)$ "Penelitian asosiatif merupakan penelitian yang bertujuan untuk mengetahui hubungan antara dua variabel atau lebih".

\section{Jenis Data}

Jenis data dalam penelitian ini adalah jenis data kuantitatif berupa kuesioner, karena data yang digunakan berupa data hasil jawaban dari kuesioner. Menurut Hadi $(2006 ; 41)$ "Data kuantitatif adalah data yang berupa angka, bukan penjelasan yang berupa kata-kata".

\section{Sumber Data}

Sumber data dalam penelitian ini adalah sumber data primer, karena jenis data yang diperoleh bisa secara langsung diolah oleh peneliti. Menurut Hadi $(2006 ; 39)$ "Data primer adalah data yang didapat secara langsung oleh peneliti dari obyek penelitian".

\section{Populasi dan Sampel}

Populasi dalam penelitian ini adalah Mahasiswa Fakultas Ekonomi Universitas Madura, dengan jumlah 877 mahasiswa yang terdiri dari 584 mahasiswa prodi Manajemen dan 293 mahasiswa prodi akuntansi.

Sampel dalam penelitian ini adalah 275 mahasiswa yang meliputi mahasiswa prodi manajemen dan akuntansi. Teknik pengambilan sampel dari setiap prodi menggunakan proportionate stratified random sampling. Menurut Sugiyono $(2008 ; 82)$ " Teknik proportionate stratified random sampling digunakan bila populasi mempunyai anggota/unsur yang tidak homogen dan berstrata secara proporsional. Berikut perhitungan sampel dari setiap prodi adalah: 


$$
\begin{aligned}
\text { Prodi Manajemen } & =\frac{584}{877} \times 275 \\
& =183,12 \\
& =183 \text { Mahasiswa }
\end{aligned}
$$

$$
\begin{aligned}
\text { Prodi Akuntansi } & =\frac{293}{877} \times 275 \\
& =91,87 \\
& =92 \text { Mahasiswa }
\end{aligned}
$$

\section{Identifikisai dan Definisi Operasional Variabel}

Variabelutama yang digunakandalampenelitianiniadalah:

1. Variabel Independent $(\mathrm{X})$ terdiridari:
a. Edukasi pasar modal $\left(\mathrm{X}_{1}\right)$
b. Modal investasi minimal $\left(\mathrm{X}_{2}\right.$
c. Return $\left(\mathrm{X}_{3}\right)$

2. Variabel Dependent( $\mathrm{Y})$ yaitu minat investasi.

3. Agar data yang diperolehdapatditarikkesimpulan, makadigunakanmetoderegresi linier bergandauntukmelihatpengaruhtigavariabel independentterhadapsatuvariabeldependentI. Metoderegresi linear ini di rumuskansebagaiberikut:

$$
\mathrm{Y}=\mathrm{a}+\mathrm{b}_{1} \mathrm{X}_{1}+\mathrm{b}_{2} \mathrm{X}_{2}+\mathrm{b}_{3} \mathrm{X}_{3}+\mathrm{e}
$$

Keterangan:

$$
\begin{array}{ll}
\mathrm{Y} & =\text { Minat Investasi } \\
\mathrm{a} & =\text { Konstanta } \\
\mathrm{X}_{1} & =\text { Edukasi Pasar Modal } \\
\mathrm{X}_{2} & =\text { Modal Investasi Minimal } \\
\mathrm{X}_{3} \quad=\text { Return } \\
\mathrm{b}_{1}, \mathrm{~b}_{2}, \mathrm{~b}_{3}=\text { Koefisien regresi } \\
\mathrm{e} \quad=\text { error }
\end{array}
$$

\section{ANALISIS DAN PEMBAHASAN}

Variabel edukasi pasar modal memiliki nilai signifikan $0,000<0,05$ sehingga $\mathrm{H}_{\mathrm{a} 1}$ diterima, artinya bahwa edukasi pasar modal berpengaruh terhadap minat mahasiswa berinvestasi saham pada Galeri Investasi Bursa Efek Indonesia Fakultas Ekonomi Universitas Madura.

Hasil penelitian ini sejalan dengan hasil penelitian yang dilakukan oleh Merawati dan Putra (2015) dan Tandio dan Widanaputra (2016) yang menunjukkan edukasi pasar modal melalui pelatihan pasar modal berpengaruh signifikan pada minat mahasiswa berinvestasi.

Edukasi mengenai pasar modal penting untuk memberikan pemahaman kepada mahasiswa tentang investasi. Edukasi mengenai pasar modal yang diperoleh mahasiswa memberikan kontribusi dalam mendorong minat berinvestasi. Edukasi ini bias dilakukan dalam bentuk matakuliah, seminar-seminar investasi, pelatihan pasar 
modal, sosialisasi pasar modal maupun melalui galeri investasi ternyata memudahkan mahasiswa dalam mengambil keputusan untuk berinvestasi.

Variabel Modal investasi minimal terhadap minat investasimemilikinilai signifikan $0,000<0,05$ sehingga $\mathrm{H}_{\mathrm{a} 2}$ diterima, artinya bahwa modal investasi minimal berpengaruh terhadap minat mahasiswa berinvestasi saham pada Galeri Investasi Bursa Efek Indonesia Fakultas Ekonomi Universitas Madura. Hasil penelitian ini sejalan dengan hasil penelitian yang dilakukan oleh Nisa dan Zulaika (2017) yang menunjukkan modal investasi mininmal berpengaruh signifikan pada minat mahasiswa berinvestasi.

Modal investasi minimal dengan dana awal yang harus disetor berkisar sebesar Rp 100.000,- dan jumlah minimal pembelian saham dari suatu emiten (perusahaan yang menjual sahamnya ke publik) adalah sebanyak 1 lot $=100$ lembar ternyata memudahkan dalam mengambil keputusan untuk berinvestasi. Bagi mahasiswa memulai berinvestasi dengan modal yang minimal memberikan kontribusi dalam mendorong minat berinvestasi.

Varibel Return memilki nilai signifikan $0,000<0,05$ sehingga $\mathrm{H}_{\mathrm{a} 3}$ diterima, artinya return berpengaruh terhadap minat mahasiswa berinvestasi saham pada Galeri Investasi Bursa Efek Indonesia Fakultas Ekonomi Universitas Madura.

Tujuan investor dalam berinvestasi adalah memaksimalkan return, tanpa melupakan faktor resiko investasi yang harus dihadapinya. Return merupakan hasil yang diperoleh dari investasi. Return juga merupakan salah satu faktor yang memotivasi investor berinvestasi. Sehingga return memberikan kontribusi dalam mendorong mahasiswa untuk berinvestasi. Hasil penelitian ini sejalan dengan penelitian yang dilakukan oleh Raditya dkk (2014) dan Tandio dan Widanaputra (2016) yang menunjukkan bahwa return berpengaruh signifikan pada minat mahasiswa berinvestasi.

\section{KESIMPULAN DAN SARAN}

1. Edukasi pasar modal, modal investasi minimal dan return secara simultan berpengaruh terhadap minat mahasiswa berinvestasi saham pada Galeri Investasi Bursa Efek Indonesia Fakultas Ekonomi Universitas Maduradengannilai signifikan 0,000 yang berarti lebih kecil dari0,05

2. Edukasi pasar modal terhadap minat investasi mempunyai nilai signifikan sebesar $0,000<0,05$ sehingga $\mathrm{H}_{\mathrm{a} 1}$ diterima. Dengan demikian edukasi pasar modal berpengaruh terhadap minat mahasiswa berinvestasi saham pada Galeri Investasi Bursa Efek Indonesia Fakultas Ekonomi Universitas Madura.

3. Modal investasi minimal terhadap minat investasi mempunyai nilai signifikan $0,000<0,05$ sehingga $\mathrm{H}_{22}$ diterima. Sehingga modal investasi minimal berpengaruh terhadap minat mahasiswa berinvestasi saham pada Galeri Investasi Bursa Efek Indonesia Fakultas Ekonomi Universitas Madura.

4. Return terhadap minat investasi mempunyai nilai signifikan $0,000<0,05$ sehingga $\mathrm{H}_{\mathrm{a} 3}$ diterima. Dengandemikian,return berpengaruh terhadap minat mahasiswa berinvestasi saham pada Galeri Investasi Bursa Efek Indonesia Fakultas Ekonomi Universitas Madura. 


\section{Saran}

1. Edukasi pasar modal, modal investasi minimal dan return hanya merupakan beberapa variabel bebas yang mempengaruhi variabel minat investasi mahasiswa (hanya44,9\%). ini berarti masih terdapat variabel bebas lain yang bisa mempengaruhi minat investasi. Bagipeneliti berikutnya dapat menambah variabel lain sepertimotivasi, resiko, umur, dan penghasilan.

2. Penelitian ini hanya dilakukan di Fakultas Ekonomi Universitas Madura. Untuk penelitian selanjutnya dapat dilakukan pada seluruh Fakultas di lingkungan Universitas Madura. 


\section{DAFTAR PUSTAKA}

Fahmi, Irham. 2006. Analisis Investasi dalam Perspektif Ekonomi dan Poplitik. PT Refika Aditama. Bandung.

Hadi, Syamsul. 2006. Metodologi Penelitian Kuantitatif.Ekonisa. Yogyakarta.

Jogiyanto. 2007. Teori Portofolio dan Analisis Investasi. BPFE. Yogyakarta.

Kusmawati. 2011. Pengaruh Motivasi Terhaadap Minat Berinvestasi di Pasar Modal Dengan Pemahaman Investasi dan Usia Sebagai Variabel Moderat. Jurnal Ekonomi dan Informasi Akuntansi Vol 1 No 2.

Merawati dan Putra. 2015. Kemampuan Pelatihan Pasar Modal Memoderasi Pengaruh Pengetahuan Investasi dan Penghasilan Pada Minat Berinvestasi Mahasiswa.Jurnal Ilmiah Akuntansi dan Bisnis Vol 10 No 2.

Nisa, Aminatun dan Luki Zulaika. 2017. Pengaruh Pemahaman Investasi Modal Minimal Investasi dan Motivasi Terhadap Minat Mahasiswa Berinvestasi di Pasar Modal. Jurnal Peta Vol 2 No 2 hal 22-35.

Pusat Departemen Pendidikan Nasional. 2001. Kamus Besar Bahasa Indonesia.Balai Pustaka. Jakarta.

Raditya, Daniel. dkk. 2014. Pengaruh Modal Investasi Minimal di BNI Sekuritas Return dan Persepsi Terhadap Risiko Pada Minat Investasi Mahasiswa dengan Penghasilan Sebagai Variabel Moderasi.E-Jurnal Ekonomi dan Bisnis Universitas Udayana 3.7.

Santoso, Setiya Bhakti. 2015. Analisis Faktor Faktor yang Mempengaruhi Keputusan Investasi Tenaga Kerja Indonesia. Jurnal Ilmiah.

Siregar, Syofian. 2013. Metode Penelitian Kuantitatif Perhitungan Dilengkapi Perbandingan Perhitungan Manual dan SPSS. Kencana. Jakarta.

Sugiyono. 2008. Metode Penelitian Kuantitatif Kualitatif dan R\&D.Alfabeta. Bandung.

Tandelilin, Eduardus. 2001. Analisis Investasi dan Manajemen Portofolio.BPFE. Yogyakarta.

Tandio dan Widanaputra. 2016. Pengaruh Pelatihan Pasar Modal, Return, Persepsi Risiko, Gender, dan Kemajuan Teknologi Pada Minat Investasi Mahasiswa.EJurnal AkuntansiUniversitas Udayana Vol 16.3 hal 2316-2341. 